\title{
GAMBARAN PENGETAHUAN DAN SIKAP PASIEN DENGAN CA MAMMAE TENTANG PEMBERIAN KEMOTERAPI DI RUMAH SAKIT ISLAM FAISAL MAKASSAR 2016
}

\author{
Rini Fitriani, Nurhikma \\ Program Studi Pendidikan Dokter Fakultas Kedokteran dan Ilmu Kesehatan Universitas \\ Islam Negeri Alauddin Makassar \\ *) email : riny.fitriani8@gmail.com
}

\begin{abstract}
Abstrak
Prevelensi penyakit kanker merupakan urutan ke 6 dari pola penyakit nasional dan menjadi penyebab kematian nomor tujuh dengan presentasi 5,7\%. Di Sulawesi selatan prevalensi kanker 4,78, di bawah angka ratarata Nasional 5,03 per mil,tetapi lebih tinggi dibandingkan dengan Provinsi Sulawesi Barat dan Sulawesi Tengah..

Penelitian ini bertujuan untuk memperoleh informasi tentang gambaran pengetahuan dan sikap pasien Ca Mammae tentang pemberian kemoterapi, dengan menggunakan metode penelitian observasi dan instrumen penelitian berupa kuisioner. Teknik pengambilan sampel dengan menggunakan purposive sampling.

Hasil penelitian menunjukkan bahwa dari 70 responden yang memiliki tingkat pengetahuan baik adalah sebanyak 34 responden $(48,57 \%)$, 29 responden $(41,42 \%)$ yang memiliki tingkat pengetahuan cukup,dan 7 reponden memiliki tingkat pengetahuan kurang. Gambaran sikap dari 70 responden terdapat 28 responden (40\%) yang memiliki sikap sangat setuju, dan 42 responden (60\%) memiliki sikap kategori setuju.
\end{abstract}

Kesimpulan dalam penelitian ini didapatkan bahwa pengetahuan sebagian besar pasien Ca-mammae adalah baik, dan sebagian besar dari mereka setuju dnegan pemberian kemoterapi pada pasien Ca-mammae.

Kata Kunci : Kanker Payudara, Pemberian Kemoterapi, Pengetahuan, Sikap

\section{Pendahuluan}

Kanker payudara merupakan jenis kanker yang paling seing menyerang kaum wanita, dimana prevalensinya setiap tahun mengalami pengingkatan. Kematian akibat kanker ini masih terbilang tinggi terutama di negara berkembang, disebabkan keterlambatan diagnosis yang berakibat pada keterlambatan pengobatan ${ }^{1}$.

Prevelensi penyakit kanker payudara merupakan urutan ke 6 dari pola penyakit nasional dan menjadi penyebab kematian nomor tujuh dengan presentasi 5,7\%. Di Sulawesi selatan prevalensi kanker 4,78, di bawah angka rata-rata Nasional 5,03 permil,tetapi lebih tinggi dibandingkan dengan Provinsi Selawesi Barat dan Sulawesi Tengah. Kanker payudara dicapai mempengaruhi kualitas hidup penduduk di negara maju, dengan semakin meningkatnya kemajuan dalam hal skrining dan pengobatan, survival rate kejadian kanker payudara telah meningkat secara perlahan ke tahap $85 \%$ di negara berkembang masih berkisar $50 \%$. $^{2}$

Kemoterapi adalah pengobatan menggunakan obat yang diberikan secara oral maupun disuntikkan. Cara kerja kemoterapi umumnya adalah dengan melemahkan sel kanker dan menghambat pembelahannya,bahkan bisa mematikan sel kanker melalui pemberian obat kemoterapi 
dosis tinggi. Di dalam tubuh, zat /obat kemoterapi sulit untuk diarahkan, sehingga bukan hanya membunuh sel-sel kanker namun juga membuh sel-sel sehat lainnya, sehingga menimbulkan efek samping ke seluruh tubuh, antara lain mual muntah, atau bahkan diare, rambut rontok/sariawan di mulut atau tenggorokan, kulit menghitam dan kering, , nafsu makan berkurang ${ }^{3}$.

Data jumlah yang melakukan kemoterapi di RS Islam Faisal pada kasus kanker payudara dua tahun terakhir yaitu tahun 2015 sebanyak 97 orang. dan tahun 2016 dari bulan januari sampai Agustus sebanyak 112 orang. Dari data tersebut maka ditemukan dari jumlah wanita $\mathrm{Ca}$ Mammae,hanya $40 \%$ yang melakukan kemoterapi dari data 240 kasus wanita $C a$ Mammae, dari data tersebut pula peneliti menyimpulkan bahwa kurangnya $\mathrm{Ca}$ Mammae yang melakukan kemoterapi diakibatkan dari tingkat pengetahuannya yang kurang tentang pemberian kemoterapi. Berdasarkan latar belakang di atas maka peneliti tertarik mengambil judul karya tulis ilmiah yaitu "Gambaran pengetahuan dan sikap ibu dengan $\mathrm{Ca}$ Mammae tentang pemberian kemoterapi" di Rumah Sakit Islam Faisal Makassar.

Resiko kanker payudara lebih tinggi pada wanita yang tidak menyusui anaknya. Dengan menyusui wanita terhindar dari resiko terkena kanker payudara sebanyak 25\%. Resiko kanker akan berkurang berbanding lurus dengan durasi menyusui kumulatif, artinya, semakin banyak jumlah bulan atau tahun ibu menyusui, semakin rendah resikonya terkena kanker payudara. Hal ini sejalan dengan perintah Allah swt kepada para wanita dalam QS. Al-Baqarah / $2: 233^{4}$ yaitu sebagai berikut :

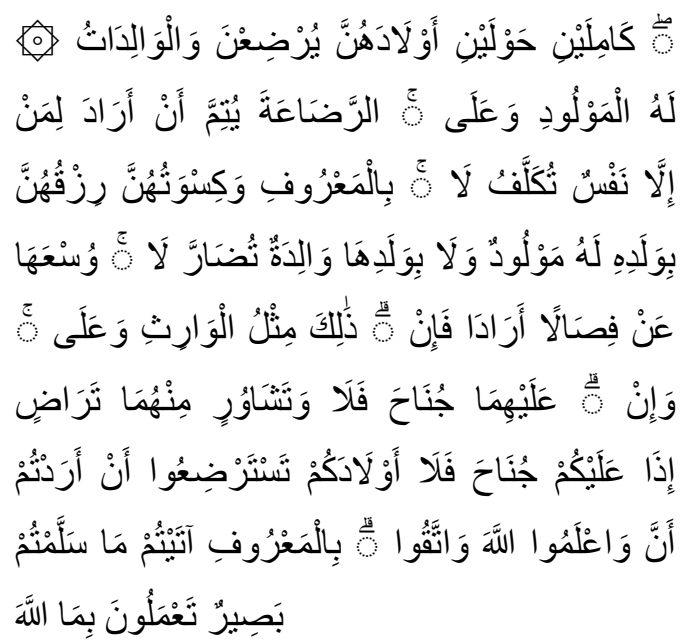

Terjemahnya :

Para ibu hendaklah menyusukan anak-nakanya selama dua tahun penuh, yaitu bagi yang ingin menyempurnakan penyusuan, dan kewajiban ayah memberi makan dan pakaian kepada pada ibu dengan cara makruf. Sesorang tidak dibebani melainkan menurut kadar kesanggupannya. Janganlah seorang ibu menderita kesengsaraan karena anaknya dan jugaseorang karena anaknya, dan warispun berkewajiban demikian. Apabila keduanya ingin menyapih ( sebelum dua tahun ) 
dengan kerelaan keduanya dan permusyawaratan, amak tidak ada dosa atas keduanya. Dan jika kamu ingin anakmu disusukan oleh orang lain, maka tidak ada dosa bagimu apabila kamu memberikan pembayaran menurut yang patut. Bertakwalah kamu kepada Allah dan ketahuilah bahwa Allah Maha Melihat apa yang kamu kerjakan ( Kementrian Agama RI, 2013 ).

\section{Metode Penelitian}

Penelitian ini dilaksanakan di Penelitian ini dilaksanakan di Rumah Sakit Umum Islam Faisal Makassar yang terletak di JL. A. Pangerang Pettarani.

Penelitian ini adalah penelitian deskriptif, bertujuan menggambarkan secara sistematis dan akurat fakta dan karakteristik mengenai populasi atau mengenai bidang tertentu.

Sampel dalam penelitian ini berjumlah 70 orang yang terdiri dari pasien yang menderita kanker payudara, dengan kriteria inklusi : didiagnosa menderita kanker payudara di Rumah Sakit Islam Faisal Makassar Tahun 2016, berdasarkan diagnosa dokter dari stadium awal hingga akhir, dan melakukan kemoterapi dan yang sementara melakukan kemoterapi. Dieksklusi sebagai sampel jika pasien tidak bersedia menjadi responden meskipun memenuhi kriteria inklusi. Sampel diambil dengan menggunakan metode purposive sampling

$$
\text { Data dikumpulkan dengan }
$$
wawancara langsung dengan responden, baik dengan menggunakan kuesioner sebagai alat ukur

\section{Hasil dan Pembahasan}

Karakteristik responden berdasarkan umur adalah mayoritas berada pada usia lebih dari 36 tahun yakni sebanyak 38 orang $(54,3 \%)$ dan berusia $26-$ 35 tahun sebanyak 32 orang $(45,7 \%)$. (lihat grafik 1). Tingkat pendidikan dapat dilihat di grafik 2 dimana mayoritas adalah SMA yakni sebanyak $42,8 \%$ (30 orang), tingkat SMP sebanyak 21,42 \% (15 orang) dan tingkat SD sebanyak 20\% (14 orang). Pekerjaan responden dapat dilihat di grafik 3, dimana mayoritas adalah ibu rumah tangga sebanyak $72,8 \%$ (51 orang), sebagai wiraswasta $17,14 \%$ (12 orang) dan PNS $10 \%$ (7 orang).

Berdasarkan umur yang diketahui bahwa sebagian besar responden mempunyai umur lebih dari 35 tahun. semakin dewasa usia seseorang maka tingkat kematangan dan kekuatan akan lebih matang dan kemampuan berpikir dan bertindak pun lebih baik. Selain umur, pengalaman dalam kehidupan sehari-hari juga turut memengaruhi tingkat 
kematangan dalam berpikir dan bertindak.

Seseorang yang berada pada tahap dewasa tengah (35-46 tahun) akan lebih kreatif, produktif dan mengembangkan kemampuan untuk merawat orang lain dan dirinya sendiri

Data untuk tingkat pendidikan menunjukkan bahwa mayoritas pendidikan responden adalah SMA, dan masih terdapat warga yang tingkat pendidikannya rendah sebanyak 20\%. Pendidikan merupakan usaha yang dilakukan untuk mengembangkan kemampuan dan kepribadian individu melalui proses atau kegiatan tertentu (pengajaran, bimbingan, atau latihan) serta interaksi individu dengan lingkungannya untuk mencapai manusia yang seutuhnya.

Pendidikan dalam hal ini menurut peneliti sangat mempengaruhi pegetahuan dan sikap wanita dengan $\mathrm{Ca}$ Mammae tentang pemberian kemoterapi. Dimana pendidikan memengaruhi pola pikir seseorang sehingga mampu menelaah sesuatu untuk disetujui atau yang tidak disetujui. Dengan pendidikan seseorang dapat mengubah perilakunya, semakin tinggi pengetahuan maka diharapkan pola pikir dan pengetahuan seseorang tersebut semakin bertambah.

Hasil penelitian yang diperoleh menunjukkan bahwa sebagian besar kaum wanita menjadi responden adalah berprofesi sebagai ibu rumah tangga.Di era global seperti sekarang ini, sumber informasi sangatlah mudah diperoleh melalui media elektronik, sehingga seorang ibu rumah tangga pun mampu memperoleh informasi yang memadai tanpa harus keluar rumah.

Wanita yang bekerja bukan lagi hal yang baru. Meningkatnya kesempatan belajar bagi kaum wanita membuka peluang bagi mereka untuk berkiprah di luar rumah, yang berefek interaksi sosial wanita tersebut pun semakin tinggi, baik kepada teman kantor ataupun orang-orang yang ditemui selama proses bekerja.

Tingkat pengetahuan dapat dilihat pada tabel 1, dimana terdapat $48,6 \%$ dengan tingkat pengetahuan baik, dan 41,4\% dengan tingkat pengetahuan cukup. Tingkat pengetahuan yang baik bisa jadi dipengaruhi dari pekerjaan responden yakni mayoritas ibu rumah tangga dan faktor usia responden yang mayoritas berada pada usia di atas 36 tahun. Menurut Notoatmodjo (2007), tingkat pengetahuan juga dapat diperoleh dari pengalaman langsung seperti informasi yang diterima dari pelayanan kesehatan dan informasi tidak langsung seperti informasi yang diperoleh dari media massa, sehingga dapat mempengaruhi tingkat pengetahuan ibu penderita kanker payudara tentang pemberian kemoterapi. Selain itu ibu penderita kanker payudara juga mempunyai rasa keingintahuan yang tinggi tentang kemoterapi. 
Tingkat pengetahuan yang cukup pada penelitian ini bisa disebabkan beberapa hal, antara lain pendidikan yang berada pada tingkat pendidikan rendah (SMA ke bawah), sehingga mengakibatkan rendahnya kemampuan mengolah informasi dan kurangnya kesadaran responden untunk mencari informasi tentang kemoterapi yang dapat diperoleh dari bebebrapa media electronic dan media cetak, ataupun kurangnya rasa ingin tahu responden tentang kesehatan pada umumnya dan kemoterapi pada khususnya. Padahal semakin tinggi tingkat pendidikan. seorang maka semakin baik pula pengetahuan yang dimilikinya, serta semakin banyak informasi yang dimiliki maka banyak pula yang diketahui sehingga mereka mempunyai tingkat pengetahuan yang baik $^{5}$

Sikap responden terhadap pemberian kemoterapi pada pasien $\mathrm{Ca}$ mammae dapat dilihat di tabel 2, dimana memberikan hasil sebagian besar $(60 \%)$ setuju dan $40 \%$ sangat setuju. Dari pengetahuan ibu mengenai pemberian kemoterapi, dapat mempengaruhi sikap ibu untuk melakukan kemoterapi, karena adanya pengetahuan tersebut tentang pentingnya pemberian kemoterapi pada ca mammae sehingga ibu dengan ca mammae cenderung untuk melakukan kemoterapi. Pengetahuan itu sendiri merupakan kemampuan seseorang untuk mengingat fakta, symbol, prosedur teknis ${ }^{5}$ Banyak faktor yang memengaruhi sikap seseorang, antara lain lembaga pendidikan dan lembaga agama sebagai salah satu sistem yang mempunyai pengaruh dalam pembentukan sikap, dikarenakan keadaanya meletakkan dasar pengertian dan konsep moral dalam diri individu. Agama sebagai salah satu system yang mempunyai pengaruh dalam pembentukan sikap, dikarenakan keduanya meletakkan dasar pengertian dan konsep moral dalam diri individu. (Wawan, 2010)

Sikap seseorang dipengaruhi oleh beberapa faktor yaitu faktor internal yaitu, umur, kesehatan, minat, motif, sedangkan faktor eksternal yaitu, informasi, lingkungan, pendidikan, social ekonomi, pengalaman yang diperoleh, situasi yang dihadapi individu, norma dalam masyarakat, hambatan, pendorong yang dihadapi individu, hal ini yang mempengaruhi seseorang mempunyai sikap positif atau sikap negatif ${ }^{5}$

Pengetahuan itu sendiri dipengaruhi oleh faktor pendidikan formal. Pengetahuan sangat erat hubunganya dengan pendidikan, diharapkan bahwa dengan pendidikan yang tinggi maka orang tersebut akan semakin luas pula pengetahuannya. Akan tetapi perlu ditekankan, bukan berarti seorang 
berpendidikan rendah mutlak berpengetahuan tidak mutlak diperoleh dari pendidkan non formal. Pengetahuan sesorang tentang suatu objek mengandung aspek positif dan aspek negatif. Semakin banyak aspek positif dari objek yang diketahui, maka semakin menimbulkan sikap positif, begitu pun sebaliknya.

\section{Kesimpulan}

Penelitian ini telah menemukan bahwa tingkat pengetahuan pasien $\mathrm{Ca}-$ Mammae tentang kemoterapi adalah baik, dan sikap mereka pada umumnya setuju dengan pemberian kemoterapi pada pasien Ca-mammae.

\section{Daftar Pustaka}

1. Bustan, M.N. (2007). Epidemiologi penyakit tidak menular. Jakarta : Rineka Cipta.

2. Kristanto, A. Y., Rahajeng, E., \& Oemiati, R. (2011). Prevalensi Tumor dan Beberapa Faktor yang Mempengaruhinya di Indonesia. Indonesian Bulletin of Health Research, 39(4).

3. Nurcahyo Jalu.2010.Mengenal Kanker Payudara, Awas Bahaya Kanker Payudara : Mengenal, Mencegah, dan Mengobati Sejak Dini Dua Kanker Pembunuh Paling Ditakuti Wanita. Yohana Totalitas Publisher, Yogyakarta. Hal 94, 98-102, 108-114.

4. Depertemen Agama RI. AL-Qur'an dan Terjemahannya. Jakarta :CVDarus Sunnah 2002
5. Notoatmodjo, S. (2010). Ilmu perilaku kesehatan. Jakarta: Rineka Cipta, 200, 26-35.

6. Arikunto, S. Prosedur Penelitian Suatu Pendekatan Praktek. Edisi Revisi V. Jakarta : Rineka Cipta,2011.

7. Ah Hangkiho - 2014.bab ii Kajian Teoretis Pengertian Sikap Jujur http://eprints.ung.ac.id/4434/9/201 2-1-86201-111410213-bab2 04092012112447.pdf.

8. Budiman, dan Agus Riyanto. Kapita Selecta Kusioner Pengetahuan dan Sikap Dalam Penelitian Kesehatan. Jakarta: Salemba Medika, 2013

9. R Paragih 2012 Peranan Dukungan Keluarga dan Koping Pasien Dengan Penyakit Kanker Terhadap Pengobatan Kemoterapi di RS 1 Rumah Sakit Umum Pusat Haji Adam.

Http://uda.ac.id/jurnal/files/rosita\% 20saragih2.pdf Sandina Dewi. 9 Penyakit Mematikan Mengenali Tanda dan Pengobatannya.Yokyakarta.2011

10. Y Yunus - 2014 .Gambaran Pengetahuan Remaja Putri Tentang Pemeriksaan Payudara Sendiri (Sadari) Sebagai Deteksi Dini Kanker Payudara di SMA Negeri 4 Kota Gorontalo. Http://eprints.ung.ac.id/5009/.

11. Yudissanta, Arief dan; Ratna, Madu 2012 Analisis Pemakaian Kemoterapi Pada Kasus Kanker Payudara Dengan Menggunakan Metode Regresi Logistik Multinomial (Studi Kasus Pasien di Rumah Sakit " $X$ ” Surabaya). Jurnal Sains dan seni its vol 1, Http://id.portalgaruda.org/index.ph p?ref=browse \&mod=viewarticle \&a $\underline{\text { rticle }=60931}$. 


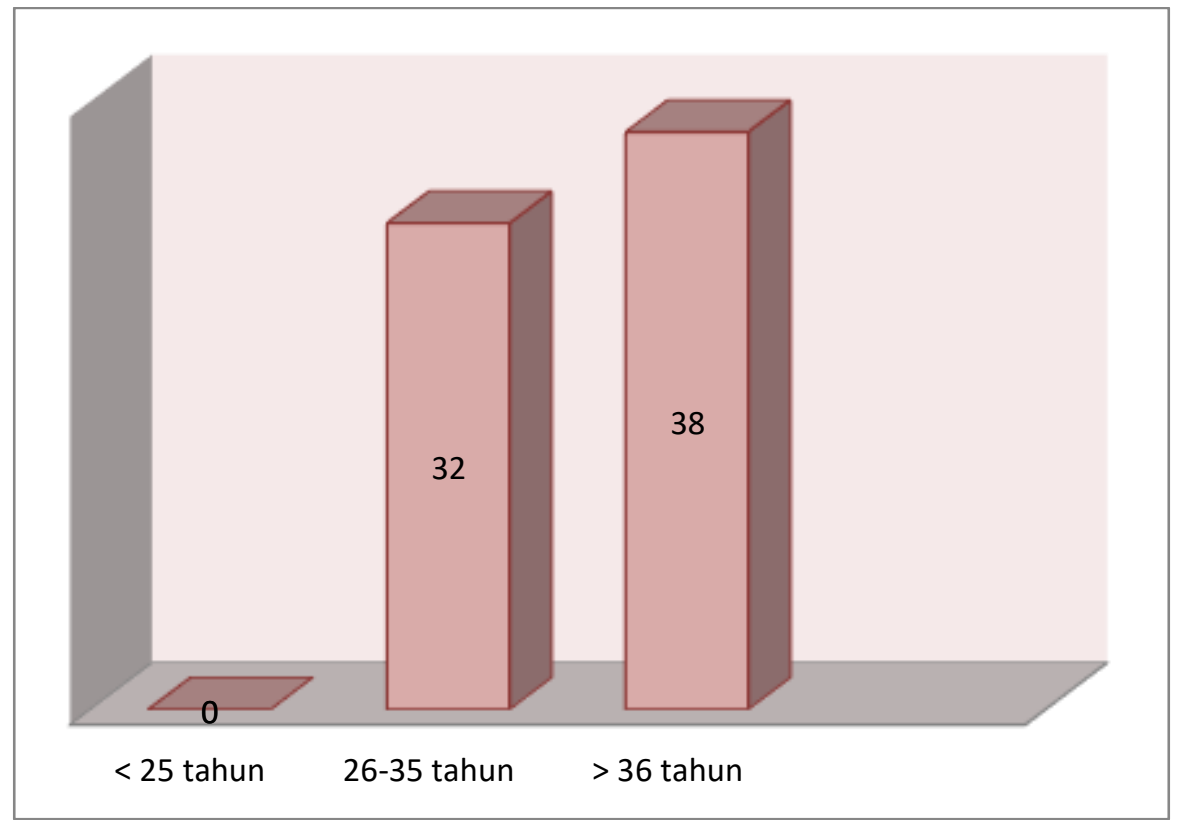

Grafik 1

Distribusi Frekuensi Karakterisitik Responden berdasarkan Umur

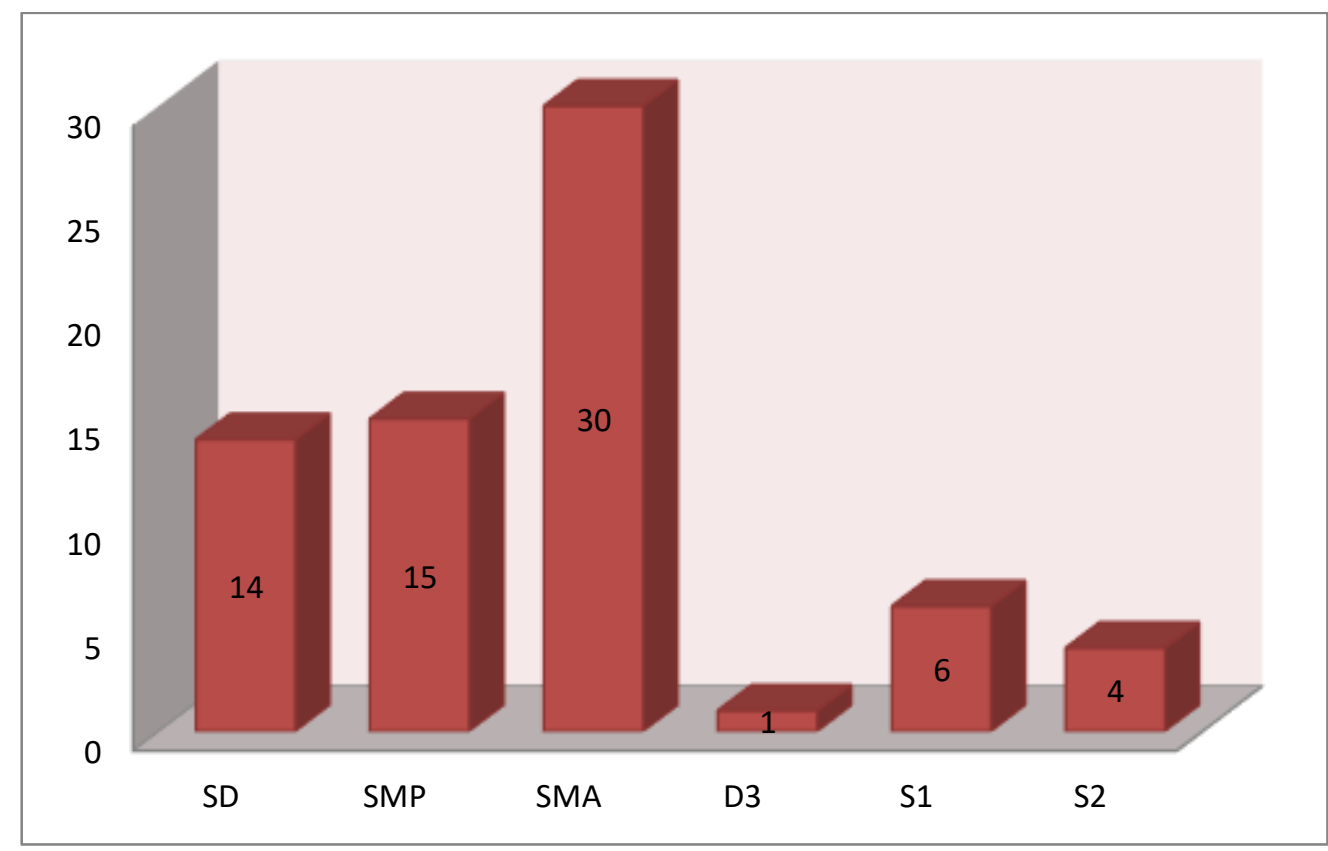

Grafik 2

Distribusi Frekuensi Karakterisitik Responden berdasarkan Pendidikan 


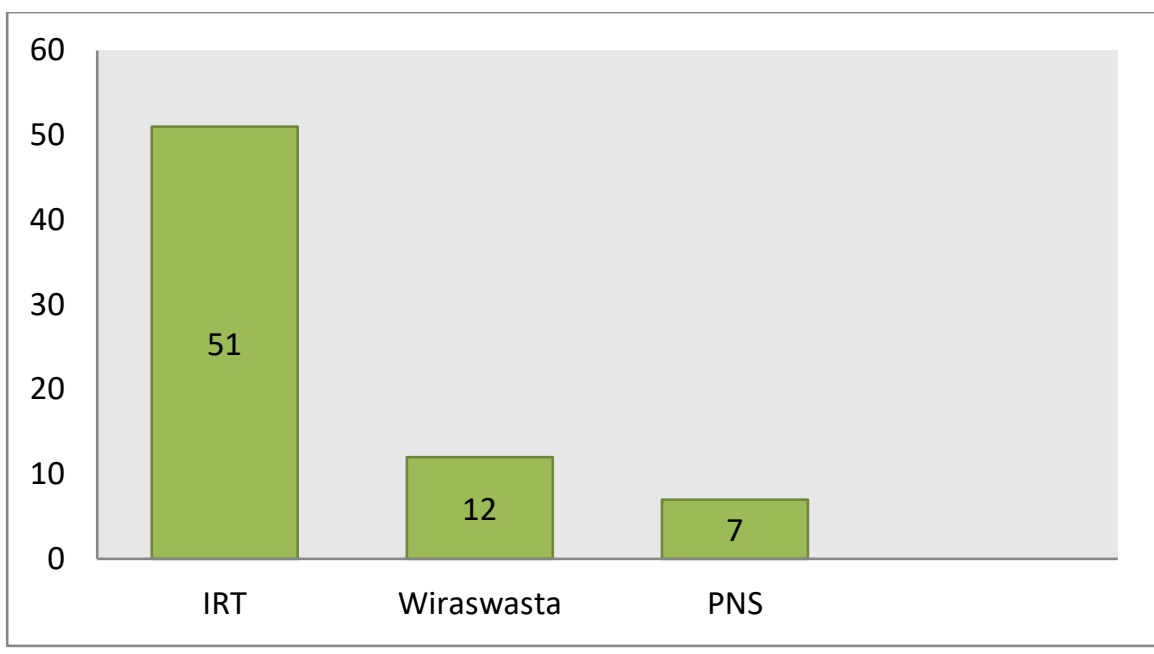

Grafik 3

Distribusi Frekuensi Karakterisitik Responden Berdasarkan Pekerjaan

Tabel 1

Distribusi Frekuensi Pengetahuan Responden tentang Pemberian Kemoterapi pada Ibu Penderita Kanker Payudara di Rumah Sakit Islam Faisal Makassar Tahun 2016.

\begin{tabular}{ccc}
\hline \multicolumn{3}{c}{ Pengetahuan responden tentang pemberian kemoterapi } \\
\hline Kriteria & N & $\%$ \\
Baik & 34 & 48,60 \\
Cukup & 29 & 41,4 \\
Kurang & 7 & 10 \\
Jumlah & 70 & 100 \\
\hline
\end{tabular}

Sumber : Kuesioner / Wawancara

Tabel 2

Distribusi Frekuensi Sikap Ibu Penderita Kanker Payudara Tentang Pemberian emoterapi Di Rumah Sakit Islam Faisal Makassar 2016

Sikap Responden

\begin{tabular}{ccc}
\hline Kriteria & N & $\%$ \\
Sangat setuju & 28 & 40 \\
Setuju & 42 & 60 \\
Ragu-ragu & 0 & 0 \\
Tidak setuju & 0 & 0 \\
Sangat tidak setuju & 0 & 0 \\
Jumlah & 70 & 100 \\
\hline
\end{tabular}

Sumber; Data Primer Diolah, 2016 